\title{
Openness and Transparency in (Slovene) Administrative Procedures as Fundamental European Principles
}

Polonca Kovač

\begin{abstract}
Openness and transparency are general administrative principles, closely related to lawfulness, accountability, responsiveness, participation and other elements of good administration. Despite their long existence in theory and legal documents, both at the European and national levels, the content and the relation of and among the respective principles is blurred. This applies even in single-case administrative procedures through the classic rights of defense, such as the right to access to information or the right to be heard. The paper explores these dimensions based on comparative analyses of the EU Charter, the OECD principles on good administration and governance and the Slovene law on administrative procedures, proving compliance between Slovene and European regulation. Furthermore, a consistent definition is proposed. Transparency is thus understood as parallel to participation. Both are seen as subcategories of openness which, as the sum of the rights of defense, is based on lawfulness and leads to accountability and ethics. However, as revealed by an empirical survey in 2015, the Slovene public administration sees these issues in a rather formal way. Finally, suggestions are made for future legislation and its implementation in terms of open and good administration.
\end{abstract}

\section{Keywords}

EU principles, openness, transparency, administrative procedure, Slovenia.

\section{Introduction}

Open administration is a concept that emerges in theory, policy papers and various supranational and national strategies within the context of reforms and the Eu- 
ropeanization of public administration. ${ }^{1}$ Namely, in public administration, public authority is exercised in a range of relations and procedures requiring legitimacy and efficiency. A significant share of public-administration relations is conducted in the form of administrative procedures as single-case decision-making, particularly in Eastern Europe. Consequently, reforms are directed also toward openness and transparency in administrative procedures (Rusch 2014; Kovač and Virant 2011, 197, 229; Koprić et al. 2014, 329ff.).

Open administration aims at a participative, accountable and hence democratic execution of authority (Banisar 2006, 18). The principle of openness has developed parallel to judicial control and opposite Weber's theory (Bugarič 2003, $120-124)$. Openness and transparency are closely connected to lawfulness, accountability, responsiveness of the authorities, etc. (see OECD 2004, 7-25; 2014; ${ }^{2}$ in detail on several aspects in Bevir 2011). Said principles constitute a set of key elements of what is known as the European Administrative Space (hereinafter: EAS), developed over the last two decades (Cardona and Freibert 2007, 53). The EAS principles are systematized in four groups: reliability and predictability (rule of law), openness and transparency, accountability, as well as efficiency in the use of public resources and effectiveness in accomplishing the goals established in legislation (OECD 1998; 1999, 9-14; 2014, 67). Likewise, the aforementioned and additional principles upgrade the EAS development in Western and Eastern Europe within the concepts of good governance and good administration (Venice Commission 2011, 3-20; Kovač et al. 2016, 136). ${ }^{3}$

The respective concepts have theoretically and practically evolved from the Weberian and German-oriented state governed by the rule of law. Their constituting principles are therefore the "classic" administrative law guarantees as well as the more contemporary or "modern" principles of good administration. In terms of EAS and good administration, openness and transparency act definitely as characteristics of current public administration or in a post-Weberian sense. This means they are something new, formed in the last few decades, together with principles

1 See Vintar et al. 2013, particularly for Eastern Europe. Open and transparent administration is explicitly mentioned, inter alia, in Articles 5 (publicity), 11 and 15 (transparency), 1, 10, 15 and 298 (openness) of the Treaty on the Functioning of the European Union (TFEU, OJ C 326/47, 26 October 2012). Transparency is - according to the Court of Justice of the European Union (hereinafter: CJEU) - also closely related to equality (see Buijze 2013; and Article 56 of the TFEU). This is similar at national levels in constitutions, umbrella laws and PAR strategies.

2 As put forward by OECD 2014, 58: "Accountability has a broader scope, which includes the organisation of the administration, openness and transparency, internal and external accountability, and oversight institutions." Or by OECD 1999, 12: "Openness and transparency are also necessary instruments for the rule of law, equality before the law, and accountability."

3 According to OECD 2004, there are eight main principles of (good) governance: the rule of law/lawfulness, participation, consensus orientation, equity and inclusiveness, transparency, responsiveness, accountability, efficiency and effectiveness. In the updated version as of November 2015 (OECD 2015), there are six groups of respective principles, among which "disclosure and transparency". 
such as efficiency and effectiveness. All these seem to be complementing the traditional principles, characteristic of the period between the $19^{\text {th }}$ century and the decades following WW2, such as lawfulness or the rule of law (see more in Nehl 1999, Rose-Ackerman and Lindseth 2010, Sever et al. 2014, Galleta et al. 2015).

Openness and transparency are most often understood as complementary twin principles; if not a synonym, at least as an inseparable unit (see, for instance, OECD 1998; 1999; 2014, or Art. 15 of the TFEU, cf. Musa 2013, 10). Such an approach is understandable since the most common definition of these principles, both in theory and official documents, sees openness as a proactive attitude of the authority available for outside scrutiny (OECD 1999, 12; cf. Bugarič 2003). The basic idea behind open government is that the government should not conduct its business secretly, behind closed doors, but rather out in the open (Brandsma et al. 2010, 5ff.). Transparency is similarly defined as a basis and a tool for the purpose of scrutiny. A transparent government provides people with the information they need to ascertain and understand the state of the world and to predict how their actions will affect them and their environment (Buijze 2013, 2). In this sense, following most references transparency represents a narrower dimension compared to openness. ${ }^{4}$ However, there are other authors who emphasize a parallel understanding of openness and transparency (Musa 2013, 12ff.) - but in this paper, we argue as the most consistent a hierarchal relation between openness and transparency as elaborated in further sections. However, both principles express the ethical dimension of good administration. ${ }^{5}$

The regulation of administrative procedures must therefore encourage the openness and accountability of public administration. Principles such as openness and transparency reflect and direct public administration on value-based regulation (Pavčnik 2007, 599). A key path to achieve such is to develop participative rights of defense in procedural law and implement them in practice. However, the exact content of openness and transparency is rather evasive and understood differently in various contexts. Some even doubt that there is one general principle of transparency in the EU law or on the national level (see Buijze 2013, 1).

In order to verify whether and how "openness and transparency" are taken into account in Slovenia, research was conducted and carried out in two steps. First, the main European documents addressing openness and transparency in admin-

4 Thus, openness is understood as C2G and transparency as G2C, hence the most important criterion of differentiating the concept is the direction of information (from the general public to the government sector or vice versa). Other criteria may be defined as instruments and results. In this respect, openness is more in an analogy with participation (i.e. receiving and elaborating such information) while transparency would mean openness of PA (to deliver information externally).

5 Ethics is a concept that concerns both individuals and groups of people, likewise in public administration. See more on ethics from legal and other aspects in a framework of accountability and good administration in Kovač 2012. 
istrative procedures were compared to key Slovene laws on the rights to access to information. Second, an empirical survey related to first-instance administrative procedures before administrative units was conducted. These agencies are the most significant in this respect since there are annually app. 1 million procedures run in Slovenia at this level. Administrative units as territorially dispersed state agencies of general jurisdiction are most closely connected to the parties (citizens and businesses), since they are conducting procedures in various specific sectors, from internal and social affairs to economy or construction.

The paper predominantly addresses legal but also broader political perspectives. The research problems tackled are, among others, the following: How are openness and transparency principles understood in political-administrative relations in general? Is there a difference on this understanding when comparing the EU and Slovene levels? Are openness and transparency principles crucial pillars of contemporary good administration or rather a bypass to more formal elements of lawfulness? Does the level of (detailed) codification of procedures affect the results in practice? Which elements of open government are most represented in Slovene administrative procedures? Can we speak of open administration in Slovenia in terms of a mere provision of information upon request, or is there proactive intercommunication? What is the role of the heads of administrative agencies in this respect? We believe that the Slovene case study can be further applied and upgraded in other countries with similar legacy, mainly German-oriented administrative culture and the post-socialist environment.

\section{Methodological framework}

The following research question is addressed: What is the understanding of the European principles of openness and transparency in the Slovene context of administrative procedures according to relevant laws and practices? There are problems common to all the countries in the region, such as strongly legally oriented PA with low capacity, lack of transparency, rather formal participation and accountability, etc. ${ }^{6}$ Regarding these, a double gap was assumed as a result of legal tradition and historical development with post-socialist characteristics in Slovenia and Eastern Europe. The first hypothesis therefore addresses a gap between European principles and Slovene rules and the second one a further gap between regulation and its implementation at the national level.

Research was thus carried out in two parts. The first part tackled the theoretical comparison of the EU-related key documents that explicitly stipulate openness

6 For more in-depth information, see Kovač and Virant 2011; Koprić 2011, 6-25; Vintar et al. 2013, 152-177; Rusch 2014; Vidačak and Škrabalo 2014, etc. Most experts argue that openness and transparency are declaratorily claimed in the reforms in the region, but there is an apparent deficit in their actual implementation. 
and transparency with the organic legislation in Slovenia. This issue was explored by means of a normative comparison of:

- European documents, i.e. OECD/SIGMA Principles of European Administrative Space (1999) and its Principles of Public Administration (2014) and the EU Charter of Fundamental Rights (hereinafter: the EU Charter; 2010) on good administration $^{7}$ versus

- The Slovene umbrella law in force since 2000 for all single-case administrative decision-making procedures, i.e. the General Administrative Procedure Act (hereinafter: GAPA; 2000), together with the Access to Public Information Act (hereinafter: APIA; 2003). ${ }^{8}$

We explored to what extent national priorities and rules comply with the EU perceived-good-administration principles. Some of the GAPA rules, for instance, obviously refer to the principles of openness and transparency, e.g. parties' access to information or the right to be heard. On the other hand, we believe that openness and transparency, due to the socialist legacy, are not fully transposed in Slovene laws as perceived by the above-listed European documents. Moreover, in this part we also expected to indirectly answer the question of how to understand openness versus transparency, in terms of their inevitably unified approach or being autonomous ones.

In the second, empirical part of the research, conducted in spring 2015, we verified the hypothesis of the anticipated implementation gap between the prescribed rules and the actual practice based on the GAPA and the APIA in Slovenia. The web-administered survey among the heads of all administrative units in Slovenia (58 in total throughout the country) was recognized as the optimal method in this respect. There are almost 1 million such proceedings per year, initiated either at parties' request or ex offcio, in the fields of internal affairs (registers and permits), construction permits, social benefits, agriculture-related matters, etc. In this part,

7 OJ C 83/389, 30 March 2010. See Art 41 on the right to good administration; Art 42 on the right to access to documents; and related Art 43 on referring to the EU Ombudsman and judiciary in a case of maladministration, with the Ombudsman's Code of Good Administrative Behaviour (2001, supplemented in 2005 and 2012). Cf. Council of Europe, CM/Rec (2007)7 on good administration with nine principles: lawfulness, equality, impartiality, proportionality, legal certainty, taking action within a reasonable time limit, participation, respect for privacy and transparency. And the earliest Resolution No. 77 (31) on the Protection of the Individual in Relation to the Acts of Administrative Authorities, with five rights: the right to be heard, access to information, assistance and representation, statement of reasons and indication of remedies. Cf. Hofmann et al. 2014, with regard to the Resolution on the Law on Administrative Procedure Act of the EU adopted by the European Parliament in January 2013, pursuing nine principles (lawfulness, non-discrimination and equal treatment, proportionality, impartiality, consistency and legitimate expectations, privacy, fairness, transparency, efficiency and service) and ten rights.

8 In Slovene: Zakon o splošnem upravnem postopku (ZUP), Official Gazette of the Republic of Slovenia 80/99 and amendments, in force since April 2000; and Zakon o dostopu do informacij javnega značaja (ZDIJZ), Official Gazette of the Republic of Slovenia 24/03 and amendments. 
the respondents were asked how they understood and pursued the individual elements of good administration as defined through the aforementioned documents and field scientific literature on good governance (more in Kovač et al. 2016). Special attention was placed on the rights stipulated by the EU Charter and the Slovene GAPA that are included under openness and transparency, namely lawfulness and responsiveness. The heads of administrative units expressed their opinions based on 17 questions in the survey, concerning their awareness and implementation of the whole set of rights and of individual rights (above all the right to be heard, the right to information, the right to use one's own language, the right to get a reasoned decision and file an appeal against it). Most questions were closed-type questions where the respondents selected one option only or ranked the given elements in order to elaborate answers as objectively as possible. Additional explanations could be provided in the concluding three open questions. The rate of response was $69 \%$, with 40 heads out of 58 participating in the survey. As a next step, structured interviews were conducted in April 2015 with four of them, representing different-sized and -located units, to clarify unexpected findings. Consequently, we find the results significantly representative despite the subjective character of the survey.

\section{Results of the analyses on openness and transparency in the Slovene administrative procedures}

\subsection{A European-Slovene comparison of the principles and rights on openness and transparency}

The EU Charter was taken as the basis for comparing the European principles on openness and transparency with the regulation in Slovenia. The Charter is a fundamental EU treaty with direct implications for European institutions. Yet, like nearly all documents at the level of the EU, it is conceived as a compilation of national good practices (Hofmann et al. 2014, 7, 34ff.; Galleta et al. 2015). Its effect on individual countries is seen in the (1) general legal principles of the European space, (2) case law at the European level and (3) spill-over effect as an indirect impact of EU rules on the Member States (Pavčnik 2007; Venice Commission 2011; Bousta 2013).

In this context, particularly relevant are Articles 41 and 42 of the EU Charter providing the right $(\mathrm{s})^{9}$ to good administration and the right to access to docu-

9 See more in Nehl $(1999,28-55)$ and Bousta $(2013,481-488)$, on the question whether there is one joined-up right to good administration or there are (only) several autonomous rights. We agree that good administration is (still) a broader concept and not a right in a legally enforceable mode. 
ments. ${ }^{10}$ Also important are Articles 43, 47 and others, for instance providing legal protection in case of infringement of Articles 41 and 42, but we only refer to the latter two to focus on openness and transparency. Indeed, there are many interrelating principles and rights. They combine also in terms of their predominantly substantive or procedural nature; particularly with regard to the connection between classic procedural rights to access one's file and broader access to public information (Savino 2010, 7 ff.). However, in the sense of good administration, both rights must be considered to be a rather harmonized or even unified right, regardless of its substantive and procedural origins. ${ }^{11}$

In the table below we thus analyzed the main elements of the right(s) to good administration, both in terms of EAS principles and in terms of the GAPA and related regulations. As regards the comparison between principles and rights under the EU Charter and EAS and good governance principles advocated by the OECD, the available literature in fact lacks a clear connection or distinction. ${ }^{12}$ This is also the reason for making a comparison focused on openness and transparency at this point.

Only later did we try to establish whether there are relevant provisions in the Slovene GAPA corresponding to said principles or rights. We were able to identify certain provisions that - although not directly linked to the elements of good administration under the EU Charter - indeed refer to said principles, such as publicity, which is an expression of transparency according to the OECD understanding of EAS. Publicity is in this sense seen as the essential linking mechanism between transparency and participation (Brandsma et al. 2010, 15).

10 Article 41, Right to good administration: "1. Every person has the right to have his or her affairs handled impartially, fairly and within a reasonable time by the institutions and bodies of the Union. 2. This right includes: the right of every person to be heard, before any individual measure which would affect him or her adversely is taken; the right of every person to have access to his or her file, while respecting the legitimate interests of confidentiality and of professional and business secrecy; the obligation of the administration to give reasons for its decisions. 3. Every person has the right to have the Community make good any damage caused by its institutions or by its servants in the performance of their duties, in accordance with the general principles common to the laws of the Member States. 4. Every person may write to the institutions of the Union in one of the languages of the Treaties and must have an answer in the same language." Article 42, Right of access to documents: "Any citizen of the Union, and any natural or legal person residing or having its registered office in a Member State, has a right of access to European Parliament, Council and Commission documents."

11 More in Kovač 2015, 187ff., see also on relevant constitutional case law in Slovenia, particularly Decision U-I-16/10 and Up-103/10, 20.10. 2011. Cf. Rose-Ackerman in Lindseth. 2010, 342.

12 See in particular Galleta et al. 2015, 22, namely the list identifying 20 principles of European administrative law. Yet, as noted by the authors themselves, several methodological levels are involved, while individual "principles" overlap in content or certain categories contain elements of other categories, although they are listed in parallel. Ibid., 17: "Although there is no established hierarchy of general principles applicable to EU administrative procedural law, not all are equal in content and scope. Some principles, such as the rule of law, good administration, or sincere cooperation are formulated in such general manner that their exact content is defined by their sub-components which, if the latter are clear, precise and unconditional also contain individual rights." 


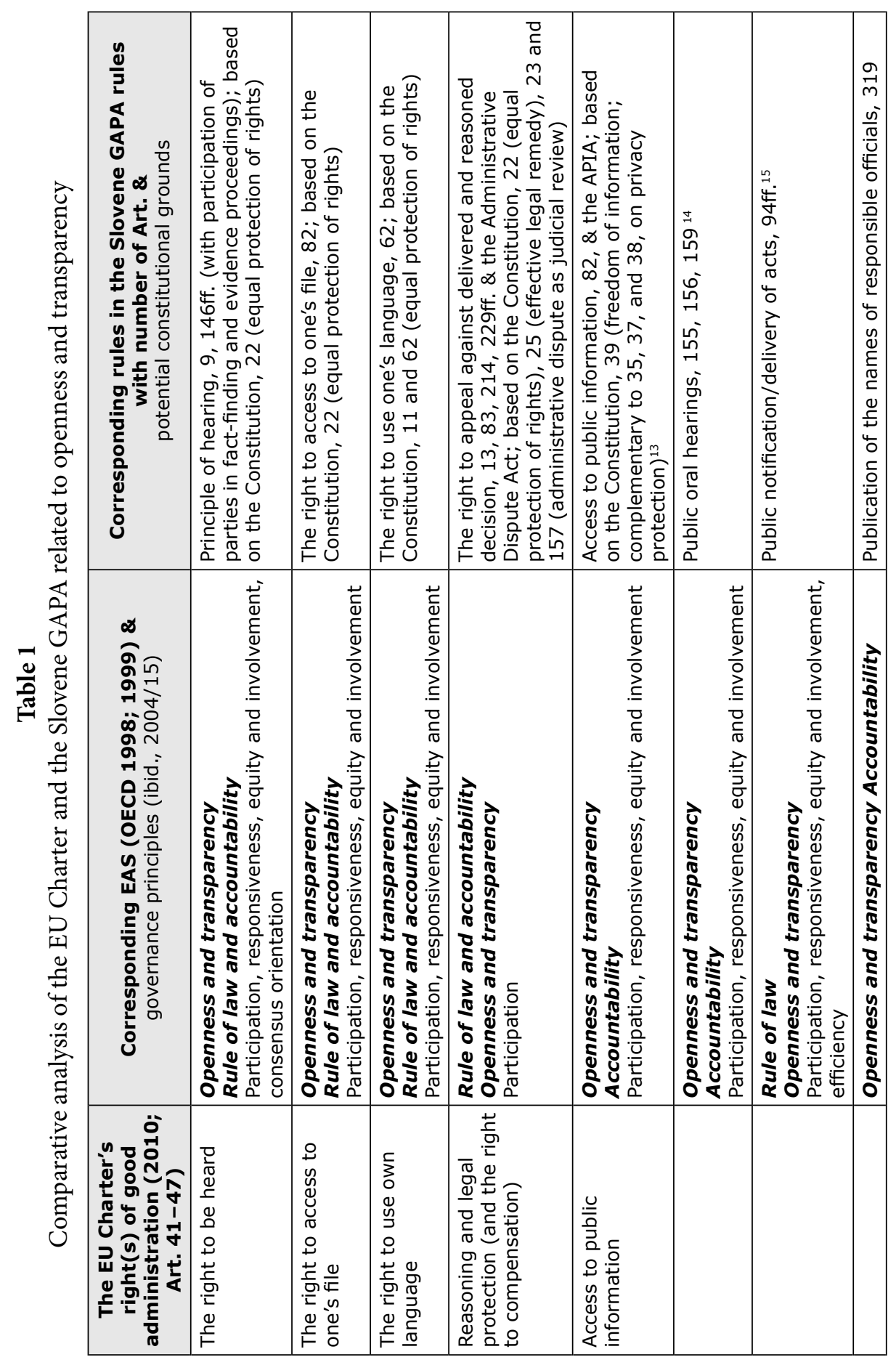




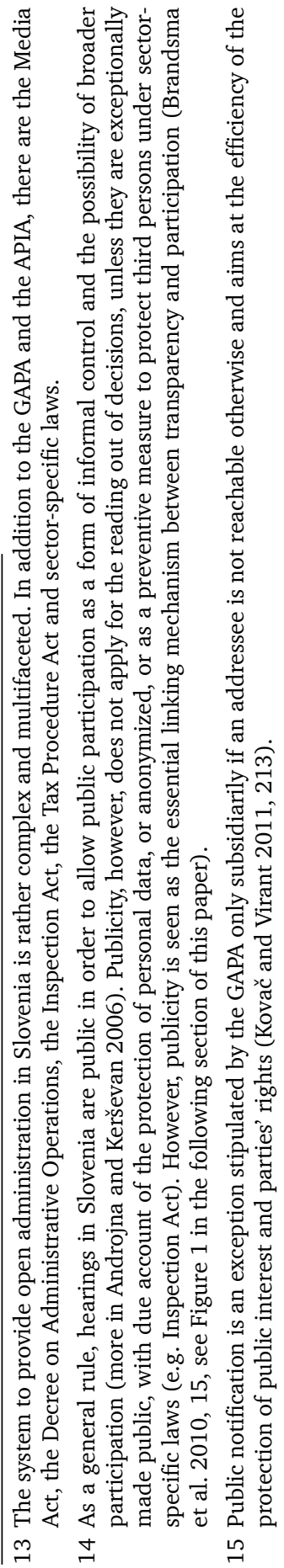


The center column clearly indicates that the rights to good administration and access to information in both the EU and Slovenia involve not only the principles of openness and transparency but also and necessarily the principles of legality, accountability and participation. In Slovenia alike, these rights are not "merely" a GAPA category but have, nearly all, a direct constitutional basis. In fact, the GAPA protects the constitutional guarantees and strives for democratic authority, yet only insofar as it involves a proactive implementation of the law, placed within the context of democratic authority (cf. Kovač and Virant 2011, 201-205; TIS 2015, 16). This points to a legal and sociological significance of the rights of defense, exceeding the regulation of administrative procedures in the formal sense.

\subsection{On openness and transparency in the practice of Slovene administrative units}

Among the results of the survey, emphasis is put on those relating to the principles of openness and transparency and the rights of defense. However, the survey's scope was broader, inquiring other aspects of good administration as well (Kovač et al. 2016). As expected, the respondents initially confirmed that the management of administrative units was fully or highly aware of the importance of the concept of good administration and instructed the officials to act accordingly in as much as $73 \%$ of the cases (i.e. 29 out of 40 heads) and at least partially aware in the remaining percentage. However, when asked about more tangible elements of good and open administration, the result proved to be rather abstract. This gap was revealed generally when the heads were asked to evaluate the importance of three categories of elements of good administration, namely legality, openness and transparency, and other participative rights of defense. We expected, in this controlling question, the heads to answer that said principles and right complied as a unit, although legality is a prerequisite for upgrading proactive administration. The heads, however, actually underlined only legality, which points to their rather limited or formal understanding of good administration.

\section{Table 2}

Priorities of legality, openness and participation in Slovene administrative units (Kovač et al. 2016)

\begin{tabular}{|l|c|c|}
\hline \multicolumn{1}{|c|}{ Prevailing principles } & $\begin{array}{c}\text { Average level } \\
(\mathbf{1 = m a x}, \mathbf{5 = m i n})\end{array}$ & Priority \\
\hline Legality/lawfulness & 1.1 & 1 \\
\hline Openness and transparency & 1.3 & 2 \\
\hline $\begin{array}{l}\text { Other rights of defense related to participation (the right } \\
\text { to be heard, etc.) }\end{array}$ & 2.5 & 3 \\
\hline
\end{tabular}

Similarly, the heads rated the impact of employee (dis)satisfaction with the implementation of the rights of defense with an average 2.5 ( 1 max, 5 min). $46 \%$ 
of the heads replied that the staff of administrative units had highly or prevailingly favorable conditions to implement the rights of defense, $41 \%$ of them evaluated the conditions as largely or totally unfavorable, while $13 \%$ saw the situation as neutral. Moreover, the heads rated the conditions for lawful work as very good (the highest score out of five) in $72 \%$ and as favorable in $92 \%$. Such perceptions were unexpected for three reasons. First, the legislation is clear and case law equally consistent that prejudicing, let alone infringing the rights of defense is an unlawful act by the administrative unit. The infringement of such procedural rights represents a significant procedural error regardless of whether the infringement (might) affect the established state of affairs and the application of legal provisions thereon (Androjna and Kerševan 2006, 30). Second, the participative rights of the parties are considered classic rights and are thus in advantage in the development of administrative law compared to the more contemporary elements of openness and transparency (see Sever et al. 2014, Galleta et al. 2015). Third, various systemic measures for the work of administrative units, in the sense of bridging the economic crisis and improving quality, scored the best results particularly in the administrative units (compared to other parts of public administration), as proven by various measurements and user-satisfaction surveys (cf. Kovač and Virant 2011, 259; Vintar et al. 2013, 168).

The survey also revealed that $80 \%$ of the heads see the users as much or at least partly more demanding than in the past. There is also an evident correlation between or influence of management on the achievement of good administration. It is better when the management of an authority is more autonomous. Such is the case, according to the respective survey, in administrative units, with an average result of 1.85 ( $1 \mathrm{max}, 5 \mathrm{~min}$ ). Moreover, $75 \%$ of the respondents see austerity measures - particularly restricted employment and training of officials - as a factor of lower pro-activity of their services. This results in increasing dissatisfaction of officials and their insisting on more formal rules. ${ }^{16}$ The above eventually affects the duration of procedures; although maximum duration is determined by law, the administrative units, despite having equal powers, differ - according to official statistics for $2012-2014$ - in as much as $20 \%$ as to the length of procedures (although $99 \%$ are concluded within (maximum) deadlines). In terms of openness and transparency, an important issue is also how the clarity of regulations affects the work of administrative units. The respondents were asked whether the regulations governing the work of administrative units were transparent and consistent (clear, coherent, mutually consistent, do not change too rapidly); $55 \%$ replied that they were not or mostly not, while $45 \%$ agreed that they were transparent and consistent, but not entirely. The average score for the transparency of regulations was thus only 2.6 (1 $\max , 5 \mathrm{~min}$ ). Therefore, it is not surprising that $85 \%$ of the heads evaluate this factor

16 During one of the interviews, we were told that in a concrete dispute between a party and an official, the latter, once the situation had been resolved, refused to shake hands with the party although instructed to do so by the superior, arguing that there is no law that binds him to do so. 
as highly or quite crucial for the gap between the principles of good administration and practice.

\section{Discussion: how to understand openness and transparency in administrative procedures}

Openness, or any other fundamental principle in public administration, is not determined as a principle or rule per se. Principles and basic rights of administrative law have evolved through time with a certain purpose (more in Galleta et al. 2015, $6 \mathrm{ff.}$.). Hence, one can fully and adequately understand these principles and rules as long as they are interpreted within their societal context.

In public administration in general and in administrative procedures in particular, where general rules are applied on individuals in an authoritative manner, the above principles need to be understood in the spirit of good administration. This means that public administration should indeed be efficient, but primarily it should be democratic. Subordinate participants in procedures need to be guaranteed fundamental rights, particularly the rights of defense. The rights of defense, including direct rights to information in one's own case or public information, are a crucial internationally recognized standard and guaranteed in the constitution (Nehl 1999, $41 \mathrm{ff}$., Kovač 2015, 188ff.). In administrative relations, where the administrative authority is a priori superior to the party, these guarantees are particularly important. The extent to which authority is restricted in fact indicates the actual degree of (non)democracy of an authority at the national level. Theory outlines a system of good governance based on law that is consensus-oriented by regulating the participative collaboration of public and private entities and organizational networking and open structures (i.e. Schuppert in Bevir 2011, 286-299).

If openness and transparency are placed in the above context, the analyses presented in the previous sections suggest that the two are not an end in itself but rather serve a dual function. First, openness and transparency act as a frame to include the affected participants in administrative relations as soon as possible in order for them to effectively protect their legal status. ${ }^{17}$ Second, openness and transparency serve to provide for the accountability and ethical behavior of the holders of public authority. ${ }^{18}$ Transparency and likewise openness therefore have rather an

17 See OECD 1999, 13: "Openness and transparency in public administration serve two specific purposes. On the one hand, they protect the public interest as they reduce the likelihood of maladministration and corruption. On the other hand, they are essential for protecting individual rights, as they provide the reasons for the administrative decision, and consequently help the interested party to exercise the right to redress through appeal."

18 Integrity (the internal moral norm) and accountability (the external norm) together stimulate the reflection of the official as well as the necessary autonomy, responsiveness and accountability of public administration (Kovač 2012, 28). See more in Bevir 2011, 373-375, on several aspects of accountability, from institutional to professional and personal. 
instrumental value for other principles (Buijze 2013, 4 and 6). If the relation between the two and other principles is defined as above, the following model can be drawn (Figure 1). All these principles in fact apply together, the one with the other to make a complete whole. ${ }^{19}$ Nevertheless, it is evident that the principle of the rule of law is the basis and lawfulness against maladministration the final goal to be achieved (see on legality as a primary principle in Sever et al. 2014, Galleta et al. 2015, 16ff.).

\section{Figure 1}

Relations among good administration and governance principles and the GAPA rights of defense

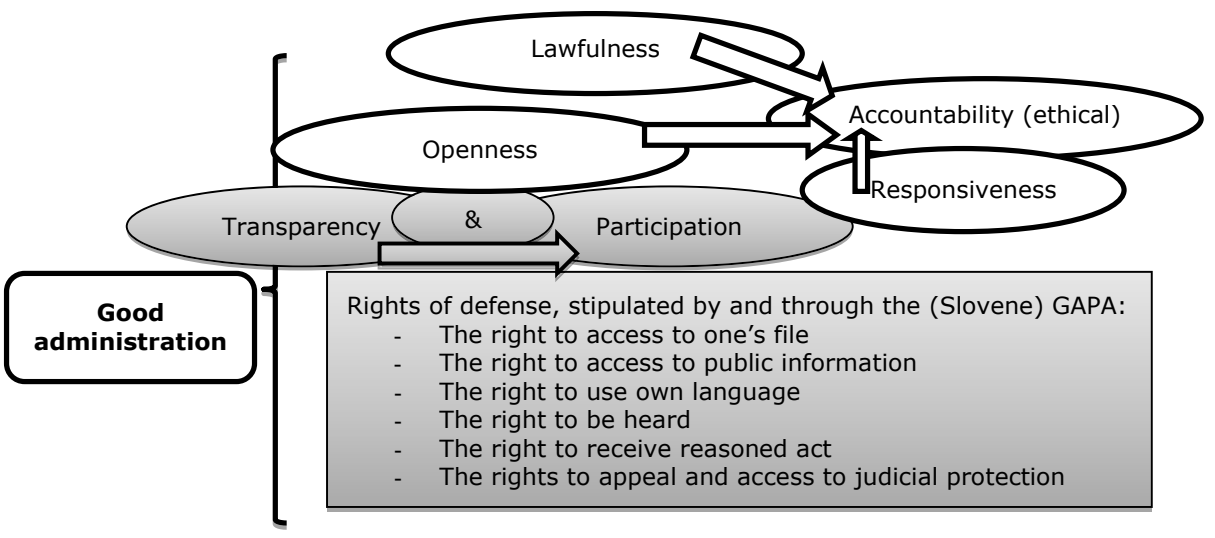

Openness and transparency serve several purposes, above all the participation of citizens, their control over public administration and greater legitimacy of the administration as long as it becomes more transparent and accountable (Savino 2010, 3; Banisar 2006, 6). Yet participation, inclusion, partnerships, openness, etc., cannot be achieved if the addressees of administrative procedures are not first informed of the purposes and goals and of the content and manner of authoritative decision-making (Kovač 2015, 189; Galleta et al. 2015, 20). Transparency therefore represents a twin principle with participation and simultaneously its prerequisite, both leading, based on lawfulness, to openness and responsiveness and finally to accountability. The suggested model answers the theoretical research problems or questions posed at the beginning of the article. The answer to the question of how to understand openness and transparency in administrative procedures is that they are just two of the several coinciding principles that together form the concepts of good governance and good administration. Yet, openness should be regarded as

19 Thus, it is not surprising that some authors see openness and participation as more connected on one side as opposed to transparency and responsiveness as the other twin (see more in Musa 2013, 11ff.). 
superior to transparency since the latter, together with participation, leads to openness through tangible rights under the GAPA and APIA. ${ }^{20}$ More so, this applies both in single-case administrative procedures and in the issuing of implementing regulations. ${ }^{21}$ The same understanding derives from European documents as well as from Slovene regulation and theory. However, in order to be fully respected, openness and transparency must be understood as elements of good administration.

In addition to the joint effect of all principles and rules, we feel it necessary to also point out the autonomous nature of individual rights, as only in such manner can the latter be enforced. This derives, for instance, from a 2011 decision of the Slovene Constitutional Court. The court argued in the respective case that the right to access to the file for persons with legal interest without the status of a party is an independent and per se legal right with a specific purpose according to Article 23 of the Constitution on access to judicial protection. Therefore, it is important that in particular the right to access to one's file and the right to public information are explicitly defined as autonomous rights, based on case law and several international legal documents. ${ }^{22}$ Both rights, regardless if regulated separately or as a joined-up right, are positive rights. That leads to them being ex-officio and pro-actively guaranteed by the state. The principle of openness is, in this framework, binding for public administration. Hence, officials must actively communicate with the parties if the democratic function of authority is to be accomplished (Bugarič 2003, Buijze 2013). A merely passive response to individual requirements under the APIA or Art. 82 of the GAPA does not suffice. Moreover, only active transparency can enable accountability.

The first hypothesis, i.e. that there is a gap between the European standards and the Slovene GAPA, is rejected. The comparative analysis in fact proved that,

20 See Buijze 2013, on "citoyen" related transparency (here as type B). There are other functions, such as regulatory quality, economic related market safety and free movement of goods, etc. Some also emphasize the relation to human dignity (ibid. as type F; cf. Nehl 1999, 20-26, 166; Rusch 2014, 197).

21 Cf. Brandsma et al. 2010, 6; Vidačak and Škrabalo 2014, 155; Kovač 2014. Different authors hereby understand openness as a sum of transparency and participation although they refer to various administrative relations (e.g. civil society in general decision-making or parties in administrative procedures). See also Galleta et al. 2015, 20 (emphasized by the author of this article): "The principles of transparency and of participatory democracy are applicable also to situations where the proceedings lead to the adoption of an act of general application including decisions with general applicability." See relevant case law as well, such as CJEU Case 64/82 Tradax v Commission [1984] ECR 1359, etc.

22 For more information on case law, see Nehl 1999, 46-54 and Pirc Musar in Kovač and Virant 2011, 241ff. as well as Kovač 2015 for Slovenia. The right to access documents is stipulated by the EU, inter alia, under TFEU (Art. 15, 42), Regulation (EC) 1049/2001 (OJ L 145) regarding Public Access to European Parliament, Council and Commission Documents, Directive 90/313/EEC on the Free Access to Information on the Environment, ECJ ruling C-465/00 on the disclosure of civil servants' income, etc. In addition, there are sector-specific acts (Buijze 2013). See also the European Convention on Human Rights, Article 10 (freedom of expression). On pro-activeness, see Trpin 2008, 157. 
at least on paper, all said principles apply also in Slovenia. Although the Slovene GAPA does not separately define the principles, as for example the Czech one on good administration or the Macedonian one on accountability do (Sever et al. 2014, 264), the rights that put openness and transparency into effect are regulated and have, as a general rule, also a constitutional basis. Thus, even the courts, in case of administrative dispute or constitutional review in administrative matters, may and do interpret the said rights in a value based context.

On the contrary, we confirmed the second hypothesis, saying that the degree of implementing the prescribed principles and rights in the spirit of openness and transparency is not (sufficiently) high to provide for a proactive behavior of administrative units in practice. The survey conducted among 40 heads of administrative units revealed that at a declaratory level, openness, transparency, participation and responsiveness are deemed crucial guidelines of their work. Contrarily, concrete answers show a discrepancy, since it is obvious that administrative units (still) stick to rather formal (procedural) norms instead of incorporating good administration principles. It can therefore be established for these units that their heads are not sufficiently aware of the necessary interdependence of all elements of good administration. In this regard, over-detailed codification of administrative procedures and freedom of expression might have a counter-productive effect (Kovač and Virant 2011, 220). Furthermore, the expectations of the parties stimulate the participation of the public administration, whereas service-minded civil servants solve the life situations of the parties in administrative procedures significantly better while balancing private and public interests (Bevir 2011, 287).

We therefore suggest a systemic revision of the Slovene GAPA, which also otherwise - when compared to other similar laws, even in the same region - appears obsolete with its excessive regulation and several shortcomings in the sense of good and participative administration (Cardona and Freibert 2007; Rusch 2014; Koprić et al. 2014, 333ff.). In this regard, it would be necessary to consider, inter alia, the introduction of new principles and individual rules following the models in the EU. ${ }^{23}$ More focus should be placed on proactive openness, broader participation of several participants in the procedure, individual accountability and servicemindedness in general. The future also calls for improvements in the sense of a more systematic approach with regard to different rights on access (Pirc Musar in Kovač and Virant 2011, 237), based on the uniform concept of the right to know. This would also broaden the scope of understanding transparency itself, nowadays often taken more or less (e.g. by Savino 2010) as access to information only, thus

23 Cf. Trpin 2008; Rusch 2014; Sever et al. 2014. A person participating in an administrative procedure has the right of access to documents on which the decision of the administration is (or will be) based in all European legal orders but not necessarily as a fundamental principle (cf. Savino 2010, 9; Venice Commission 2011). The principle of transparency may thus be found in the Hungarian GAPA of 2004 and could serve as a model for Slovenia, which could in turn be a model for other countries. 
providing grounds for a "culture of openness" based on pro-activity (Banisar 2006, 32; Brandsma et al. 2010, 8).

\section{Conclusions}

Given the superior position of the authority in administrative matters, public administration must develop forms of cooperation with the public in order to be fair and efficient. Openness and transparency of public administration are thus at the same time a prerequisite and the objective of good administration and good governance at the national and global levels. However, these dimensions need to be understood in parallel with participation and other guiding principles to lead to their full effect. Good and open administration is a holistic concept that can be fully realized only when all its elements are balanced and interdependently achieved.

In administrative procedures, which record a growing trend within the modern society, openness of administration is achieved primarily by procedural legal entitlements of the parties, i.e. the ruled in their relations with the rulers. These rights simultaneously affect transparency and participation, which in combination enable open administration. This idea is, according to the comparative analysis, implemented in the Slovene GAPA, since it provides all principles and fundamental rights as acknowledged at the European level. However, there is a gap in terms of implementation. Since openness and transparency aim at a value-based good administration, there is inevitably a further need to enhance awareness of the respective principles. According to the findings of analyses presented in this paper, further steps require a changed approach, namely strategic support in the overall administrative system instead of new amendments to existing norms as has been the case so far. In the long run and in the wider context, the procedure should not be considered - as it has been for decades - merely as a way to protect the rights (even constitutional ones) of the weaker parties. Similarly, it should not be regarded exclusively as a field of de-bureaucratization in the framework of neoliberalism and short-term reduction of administrative barriers on the account of achieved European civilization principles. The right way is a holistic one, such that the elements of transparency and participation under the GAPA lead to lawfulness, openness and accountability. In this respect, general administrative principles and rights stipulated by the EU documents can indeed serve as a guide to national policy-makers and administrative authorities.

\section{References}

Androjna, Vilko and Erik Kerševan. 2006. Upravno procesno pravo [Administrative Procedural Law]. Ljubljana: GV. 
Banisar, David. 2006. Freedom of Information around the World 2006. Available at http://www.humanrightsinitiative.org/programs/ai/rti/international/laws_ papers/intl/global_foi_survey_2006.pdf (last accessed 19 October 2016).

Bevir, Mark (ed.). 2011. The SAGE Handbook of Governance. Los Angeles: Sage.

Bousta, Rhita. 2013. "Who Said There is a 'Right to Good Administration?' A Critical Analysis of Article 41 of the Charter of Fundamental Rights of the European Union." European Public Law 19(3), 481-488.

Brandsma, Gijs Jan, Deidre Curtin, Bettina Leufgen and Albert Meijer. 2010. "Studying Open Government in the EU: From Normative Debates to Empirical Fact-Finding." ECPR/SGEU conference, Oporto, 24-26 June 2010. Available at http://www.jhubc.it/ecpr-porto/virtualpaperroom/035.pdf (last accessed 19 October 2016).

Bugarič, Bojan. 2003. "Odprta javna uprava" [Open Public Administration]. Zbornik znanstvenih razprav 63, 119-156.

Buijze, Anoeska. 2013. "The Six Faces of Transparency." EGPA conference, Edinburgh, 11-13 September 2013.

Cardona, Francisco P. and Annke Freibert. 2007. "The European Administrative Space and Sigma Assessments of EU Candidate Countries." Croatian Public Administration 7(1), 51-59.

Galleta, Diana-Urania, Herwig C. H. Hofmann, Oriol Mir Puigpelat and Jacques Ziller. 2015. "The General Principles of EU Administrative Procedural Law. Brussels: European Parliament." Available at http://www.europarl.europa.eu/ RegData/etudes/IDAN/2015/519224/IPOL_IDA(2015)519224_EN.pdf (last accessed 19 October 2016).

Hofmann, Herwig C. H., Jens-Peter Schneider and Jacques Ziller (eds). 2014. The ReNEUAL Model Rules. ReNEUAL. Available at www.reneual.eu (last accessed 19 October 2016).

Koprić, Ivan. 2011. "Contemporary Croatian Public Administration on the Reform Waves." Yearbook of the Croatian Academy of Legal Sciences 2(1), 1-39.

Koprić, Ivan, Gordana Marčetić, Anamarija Musa, Vedran Đulabić and Goranka Lalić Novak. 2014. Upravna znanost [Administrative Science]. Zagreb: Faculty of Law.

Kovač, Polonca. 2012. "Ethics of Officials in the Context of (Slovene) Good Administration." The NISPAcee Journal of Public Administration and Policy 5(1), 23-53.

Kovač, Polonca. 2015. "Contemporary Challenges of Access to Information in Public Governance in South Eastern Europe." Lex Localis 13(2), 185-204. Doi:10 .4335/13.2.185-204(2015) (last accessed 19 October 2016). 
Kovač, Polonca, Tomaževič, Nina, Leben, Anamarija and Aleksander Aristovnik. 2016. "Reforming public administration in Slovenia: between theory and practice of good governance and good administration." International Journal of Public Policy, 12 (3/4/5/6), 130-148. Doi: http://dx.doi.org/10.1504/ IJPP.2016.10000529 (last accessed 19 October 2016).

Kovač, Polonca and Gregor Virant (eds). 2011. Razvoj slovenske javne uprave 1991-2011 [Development of Slovene Public Administration 1991-2011]. Ljubljana: Official Gazette of the Republic of Slovenia.

Musa, Anamarija. 2013. “Transparentnost - zašto i kako?” [Transparency - Why and How?]. In Musa, Anamarija (ed.). 5. Forum za javno upravu. Zagreb: Friedrich Ebert Stiftung, Institut for Public Administration, 7-26. Available at http://www.iju.hr/page15/files/5_FORUM_stranice.pdf (last accessed 19 October 2016).

Nehl, Hanns Peter. 1999. Principles of Administrative Procedure in EC Law. Oxford: Hart.

OECD. 1998. Preparing Public Administrations for the European Administrative Space. SIGMA Papers 23. Paris: OECD.

OECD. 1999. European Principles for Public Administration. SIGMA Papers 27. Paris: OECD.

OECD. 2004. Principles of Corporate Governance. Paris: OECD.

OECD. 2014. The Principles of Public Administration. Available at http://www.sigmaweb.org/publications/Principles-Public-Administration-Nov2014.pdf (last accessed 19 October 2016).

OECD. 2015. G20/OECD Principles of Corporate Governance. Paris: OECD. Doi: http://dx.doi.org/10.1787/9789264236882-en (last accessed 19 October 2016).

Pavčnik, Marijan. 2007. Teorija prava [Theory of Law]. Ljubljana: Cankarjeva založba.

Rose-Ackerman, Susan and Peter L. Lindseth (eds). 2010. Comparative Administrative Law. Cheltenham, Northampton: Elgar.

Rusch, Wolfgang. 2014. "Citizens First: Modernisation of the System of Administrative Procedures in South-Eastern Europe." Croatian and Comparative Public Administration 14(1), 189-228.

Savino, Mario. 2010. The Right to Open Public Administration in Europe: Emerging Legal Standards. SIGMA Papers 46. Paris: OECD. Available at http://www. epsa2011.eu/files/Themes_2011/OECD\%20Administrative\%20Transparency\%201010.pdf (last accessed 19 October 2016). 
Sever, Tina, Iztok Rakar and Polonca Kovač. 2014. "Protecting Human Rights through Fundamental Principles of Administrative Procedures in Eastern Europe." Danube 5(4), 249-275.

Transparency International Slovenija (TIS). 2015. Ali so inšpekcijski postopki res transparentni in učinkoviti? [Are inspection procedures really transparent and efficient?]. Ljubljana: TIS. Available at http://issuu.com/tislovenia/docs/ pp_inspekcije/1 $? \mathrm{e}=14269436 / 31675245$ (last accessed 19 October 2016).

Trpin, Gorazd. 2008. "The Process of Communication between Citizens and Public Authority Bodies - a New Concept of General Administrative Procedure." Lex Localis 6(2), 153-169.

Venice Commission. 2011. Stocktaking on the Notion of Good Governance and Good Administration. Study 470/2008, CDL-AD(2001)009.

Vidačak, Igor and Marina Škrabalo. 2014. "Exploring the Effects of Europeanization on the Openness of Public Administration in Croatia." Croatian and Comparative Public Administration 14(1), 149-187.

Vintar, Mirko, Alan Rosenbaum, Gyorgy Jenei and Wolfgang Drechsler (eds). 2013. The Past, Present and the Future of Public Administration in Central and Eastern Europe. Bratislava: NISPAcee. 